\section{Review on impacts of COVID-19 pandemic on life animals and dairy product processing industries of the world}

\section{Lammifyad Chimde*}

Department of Animal and Range Science, College of Agricultural Science, Bule Hora University, Ethiopia

\section{Abstract}

This review was conducted for the objective of assessing causes of COVID-19 pandemic impacts on life animals and dairy product processing industry of the world. Since its outbreak in Wuhan town of China, the newly emerged strains of corona virus COVID-19 causes incredible crisis both on life animal and its product especially dairy industry of the globe. During the outbreak of the virus, majority of the world people were stayed home to prevent the spread of the diseases. At that time, the wildlife found in the zoo were exposed to diseases and missed human attention, global wildlife trade was spotlighted and wildlife was running... wild. For the reason of COVID-19 pandemic, many schools and restaurants which received dairy product from dairy producers and cooperatives were shutdown. Due to schools and restaurant shutter, milk supply chain was disrupted. For this moment milk demand and supply was decreased, huge volume of milk was dumped, mode of milk trade was changed, market and farm prices was fluctuated, import- export route was interrupted and Farm workforce absenteeism were some of the challenges cases dairy industry crisis. Trade law modification, provision of financial assistance for dairy industry and farmers, and expansion of export route were the measures taken by concerned bodies to save dairy industry from corona virus crisis. Therefore, COVID-19 pandemic is the disaster diseases which causes social and economic crisis on dairy producers of the world. So, to save wildlife and dairy industry from corona virus crisis, global solidarity prevention is mandatory.

\section{More Information}

*Address for Correspondence: Lammifyad Chimde, College of Agricultural Science, Bule Hora University, Oromia Regional State, Ethiopia, Tel: 251+0912983272;

Email: chimdetesfaye@yahoo.com; lammifyadchimde@gmail.com

Submitted: 13 May 2020

Approved: 21 May 2020

Published: 22 May 2020

How to cite this article: Chimde L. Review on impacts of COVID-19 pandemic on life animals and dairy product processing industries of the world. Insights Vet Sci. 2020; 4: 018-024.

DOI: 10.29328/journal.ivs.1001022

Copyright: @ 2020 Chimde L. This is an open access article distributed under the Creative Commons Attribution License, which permits unrestricted use, distribution, and reproduction in any medium, provided the original work is properly cited.

Keywords: COVID-19 pandemic; Dairy industry; Wildlife

W) Check for updates

OPEN ACCESS

\section{Introduction}

Corona virus disease was first described in 1931, with the first corona virus (HCoV-229E) isolated from humans in 1965. Until the outbreak of severe acute respiratory syndrome in late 2002, only two human corona viruses ( $\mathrm{HCoV}$ ) were known - HCoV-229E and HCoV-OC43. Once the SARS corona virus (SARS-CoV) had been identified, two further human corona viruses were identified [1]. Corona viruses are large family of viruses that are known to causes illness ranging from the common cold to more severe diseases such as Middle East Respiratory Syndrome (MARS) and Severe Acute Respiratory Syndrome (SARS).

Bovine corona virus (BCoV) is an important livestock pathogen with a high prevalence wide. The virus causes respiratory disease and diarrhea in calves and winter dysentery in adult cattle. These diseases result in substantial economic losses and reduced animal welfare. One way of reducing the negative consequences of this virus is to prevent virus transmission between herds. Inter-herd transmission is possible either directly via transfer of live animals or indirectly via contaminated personnel or equipment [2].

Now a days, new strains of corona virus which is known as novel corona virus (COVID-19) was recognized in 2019 in Wuhan, China. This is the new species of virus that has not been previously identified in human. This newly emerged strain of corona virus is very common both in human and animals (WHO, 2020).

According Gabriele, report [3], the newly emerged COVID-19 pandemic is threaten for the people living on the world today because human beings are not develop immunity system to prevent themselves from this new strains of viruses if it will seriously spread within the communities.

The present COVID-19 pandemic is different from human 
and bovine corona viruses that were identified earlier because the COVID-19 pandemic has great incidences to attack human being and livestock. Comparatively, Bovina corona virus and the newly emerged COVID-19 have the potential to causes economic losses on life animals and dairy industry of the world. Therefore, the current review was designed to assess the impact caused by COVID-19 on life animal and dairy product processing industries of the globe.

\section{Objective}

To review the impact of COVID-19 pandemic on life animal and dairy product processing industries of the world.

\section{Litereture review}

\section{Taxonomy of corona virus}

Corona viruses and toro viruses are two virus genera within the virus family Corona viridae, order Nido virales. Corona viruses are well-established pathogens of humans and animals while the toro viruses are recognized as causes of animal diarrhea. Toro viruses have also been found in human faeces but their etiological role remains unclear [4].

Corona viruses are classified into three groups, initially based on antigenic relationships of the spike (S), membrane (M) and nucleocapsid (N) proteins and now re-enforced by viral genetic phylogeny. The HCoVs 229E and NL63 are group 1 corona viruses, while OC43, HKU-1 and SARS corona viruses are classified in group 2. Group 3 corona viruses are found in avian species. Genetic recombination readily occurs between members of the same and of different corona virus groups providing opportunity for increased genetic diversity [4].

Efforts to identify the animal reservoir of SARS corona virus led to the discovery of diverse bat corona viruses in both group 1 and 2 that are closely related phylogenetically to different mammalian corona viruses. It has been proposed that bat corona viruses may indeed have been the ancestors of many mammalian corona viruses [4].

\section{Impact of COVID-19 on life animals}

The COVID-19 pandemic causes dramatic impact on animals across the globe, too, from the coughing tiger in New York to emboldened goats on the streets of Wales. As Josephine Moulds posted his own view point by witnessing the Economic Forum [5], the COVID-19 Pandemic affects animal through the following three ways:

Global wildlife trade is in the spotlight: The pandemic is thought to have originated at a market selling wild animals in China, throwing a spotlight on the global wildlife trade. The New York-based Wildlife Conservation Society is urging governments to ban live animal markets, and stop illegal trafficking and poaching of wild animals. In the wake of the initial outbreak in Wuhan, China introduced a ban on all farming and consumption of live wildlife. After the corona virus outbreak was seen in China, there were growing calls for countries around the world to ban "wet markets" - which sell live and dead animals for human consumption - to prevent future pandemics. Elizabeth Maruma Mrema, acting executive secretary of the UN Convention on Biological Diversity, and Jinfeng Zhou, secretary general of the China Biodiversity Conservation and Green Development Foundation, have added their voices to calls for authorities to make the ban on wildlife markets permanent.

Zoo animals are getting sick and missing human attention: The corona virus is a zoonotic disease, meaning it jumped from animals to humans. Now, it seems to be jumping back. On 07 April 2020, news emerged that a tiger at the Bronx Zoo tested positive for the corona virus. It is thought the tiger, named Nadia, along with six other big cats, were infected by an asymptomatic zoo keeper. The cats have been showing symptoms, including a dry cough. Paul Calle, the chief vet at the zoo, told Reuters, "This is the first time that any of us know of anywhere in the world that a person infected the animal and the animal got sick."

The US Centers for Disease Control and Prevention (CDC) has since reiterated that there is no evidence yet that pets can spread COVID-19 to people or that they might be a source of infection in the US. Zoos across the globe have been closed as part of national lockdown and zookeepers says their most intelligent and social animals - including gorillas, otters and meerkats - are missing the attention of humans. Nathan Hawke (2020), from Orana wildlife park in New Zealand, told the Guardian that many rare and endangered animals continued to show up for their daily "meet the public" appointments despite the fact there is nobody there to watch them. The issue of the guardian was to save the rare and endangered species of animals found in the park from COVID-19 pandemic loses by providing close care and watch to maintain the future generation of these animals.

Zoo animals' new found privacy may have had some unexpected benefits. In Ocean Park in Hong Kong, it is thought that Ying Ying, one of the resident pandas, may be pregnant after 10 years of attempts at natural mating. Due to the corona virus outbreak, the park has been closed to visitors. Michael Boos, executive director at Ocean Park, said, "The successful natural mating process today is extremely exciting for all of us, as the chance of pregnancy via natural mating is higher than by artificial insemination".

Wildlife is running...wild: With humans self-isolating in their homes, animals that usually stay away from urban areas now have space to roam. In northern India, a herd of deer was caught on camera walking the streets of Haridwar during the nationwide COVID-19 lockdown. Moreover, wild boars have been spotted in the centre of Barcelona, Spain. In Wales, mountain goats are causing havoc on the streets of Llandudno. While rival gangs of monkeys brawled over food in Lopburi, Thailand. 
Becky Thomas, senior Teaching Fellow in Ecology, Royal Holloway, says there will be winners and losers from this temporary change in human behavior. In the UK, hedgehogs are enjoying relatively car free roads, but ducks, which rely on food provided by humans, are going hungry.

\section{Crisis of COVID-19 pandemic on dairy industries}

The outbreak of COVID-19 pandemic causes unexpected crisis on agricultural processing industries as general and dairy product processing companies as a particular. As able to understood from countries and Organizational report, COVID-19 pandemic causes huge economic and moral loses on dairy, beef, poultry and pork industries of the world.

Crisis on dairy product demand and supply: As corona virus continues to spread, industries across the globe are starting to evaluate the impacts that the outbreak will have on their businesses. Despite the increased demand for products as consumers stock up shelves for potential quarantines or to limit their trips to the grocery store, keeping up with that demand and securing the supply chain has not been an easy feat [6].

With more travel restrictions in place because of the risk of spreading the disease, exports both to and from China have been impacted, hurting the positive trajectory that dairy was on globally. Although demand from China is beginning to recover after its virus exposure appears to have hit its peak, cases will likely continue to increase in the U.S. in months after March. Rabobank lowered its 2020 U.S. demand growth projections from $0.8 \%$ to $0.5 \%$. Based on the forecast through 2020, Rabobank is predicting a down cycle in global dairy markets [6].

Analysts are expressing concern over the slowing export demand for dairy, not because they see less consumer use, but because shipments need to go through more protocols and procedures to get to some locations around the world. This could back up supply and result in lower prices that could hurt the industry [6].

In the short term though, the demand for dairy could be a positive if suppliers are able to keep shelves stocked. Some dairy farmers are saying they have seen an increase in business as milk and yogurt is flying off the shelves. It will likely be challenging for producers to keep up with demand as the virus spreads. U.S. dairy operations could face a risk to their workforce if the virus is found in areas where farms are located [6].

The dairy industry has faced numerous ups and downs in recent years before the corona virus even came into the picture. Two major milk producers have filed for bankruptcy in recent months as consumers turn to cheaper private label products, alternative beverage choices and plant-based options. As shoppers stock up, they are also turning to dairy alternatives. In the first week of March, oat milk sales were up $347.3 \%$, according to Nielsen data. It's not just the dairy industry that is facing an impact from the virus. Representatives and analysts have said that the corona virus threat may disrupt the beef and pork industries as they face worker shortages and demand issues.

As dairy processors association of Canada (2020) shows, dairy processors across the Canada's country have been responding to federal and provincial calls to support social distancing in order to flatten the COVID-19 curve, while also ensuring that operations continue with limited or no disruption to the food supply chain. Dairy plants have business continuity plan and crisis management teams in place to protect the health of their employees while continuing services in the company. Due to this only essential production and warehouse staff are attend the work; all office staff have been advised to work remotely. Due to the employee deduction the production capacity of the company drops. This brought as demand and supply is unbalanced.

By nature of the food processing plant, very strict hygienic measures are already in place to support federal and provincial food safety requirements. Many processors are enhancing health measure to those essential staff that comes to work every day in order to services the country.

In Bangladesh despite the increased demands for dairy products as consumers stock up shelves for potential quarantines or to limit their trips to the grocery store, keeping up with that demand and securing the supply chain has not been an easy feat [7]. With more travel restrictions in place because of the potential risk of spreading the diseases, export both to and from china have been impacted, hurting the positive trajectory that dairy was on globally. Because of viral outbreak, dairy products imported to china from USA and other countries were potentially hurdled. This will be leading the increment of milk stock in major exporting countries; thus, will have impact on reducing world milk price in the long-run [7].

Product loses/dumping: In order to prevent the spreads of COVID-19 pandemic, many restaurants, school, café and companies which receive milk from the producers were temporarily shutdown in variety of the continent. So, many milk producers were faced with interruption of market chain. For this evident, it is possible to take few countries and companies as example. For instance, in West Midlands, some farmers were thrown away thousand liters of fresh milk due to disruption to the supply chain caused by corona virus. This is concern that some dairy farms may go out of business, which results in a milk shortage when demand returns after the pandemic [8].

A similar challenge was faced Vermont dairy farm. As VT Digger [9] (2020, time on face book) wrote, "the economic crisis brought by on the new corona virus is taking a toll on Vermont's farms, forcing some dairies to dump milk as 
demand has dried up." Similarly, Anson Tebetts (2020), the secretary of the agency of Agriculture Vermont, said that: "the worst month for dairy producers will likely be between April and August, as the consumption of milk continues to fall, and with it compensation for dairy farmers". Dairy farmers for America, of which the St. Albans Cooperative Creamery and its 350 members is a subsidiary confirmed as certain dairy farm in Vermont have dump milk since the outbreak of COVID-19. While milk is beginning to be dumped, Vermont's cheese makers, crippled by the closures of restaurants and farmers markets are also facing the harsh reality of business during the time of COVID-19.

Similar to other countries the dairy cooperatives in England's dumped dairy surplus due to the outbreak of COVID-19 pandemic. In the wake of the COVID-19 pandemic, the dairy industry saw two of its major markets- restaurants and schools- dry up overnight leading to surplus of milk nationally and the dumping of millions pounds of milk that could not be sold [10-12]. Ron Johnson, policy director for the New Hampshire farm Bureau, noted $7 \%$ of all milk produced by the largest dairy cooperative in the country nationwide was dumped in one week in early April due to surplus. Hall (April 2020), director of Granite state dairy promotion stated that, "while the amount of milk dumping in New Hampshire was not known, dairies in New England have dumped 18 million pounds of milk in the past three weeks." This severe crisis faces the dairy farmers due to the school market and restaurants were shuttered because of the virus outbreak.

According to Huffstutter, [13] report, dairy farm in North American continents was extremely attacked by the newly emerged COVID-19 Pandemic. Despite strong demand for basic foods like dairy products amid, the corona virus pandemic the milk supply chain has seen a host of disruptions that are preventing dairy farmers from getting their products to market. Leedle the US dairy producer stated as he dumped 4,700 gallons of milk from his 480 cows each day. When the coronavirus pandemic hit in the US, it also led to many farmers having to dump enormous amounts of milk, not only in the US but also in Canada and in the UK.

Change milk trade actors and shortage of transportation: Milk is a dairy product which consist huge volume of water $(87 \%)$. This water content makes milk as it can easily perishable. In order to keep the milk with its natural states, the dairy producers should be processing it in to other dairy product. Because of its perishable properties, it should be arrived soon to the processing plants after harvest. However, during the outbreak of corona virus, the dairy business got hit harder and earlier than other agricultural commodities because the products are highly perishable - milk can't be frozen, like meat, or stuck in a silo, like grain Huffstutter [13].

The dairy farms in the US sold fresh milk to the restaurants and schools in the form of wholesale. But due to the COVID-19 pandemic, in US mass number of restaurants and schools which received fresh milk in wholesale from dairy farms was shutdown. Because of these institutional closer milk supplies chain was disrupted for a time being. For this reasons the United States agriculture, food and beverage pressured to change raw milk trade strategies to save the dairy farms from crisis. Then the dairy producers found in US were forced a sudden shift from those wholesale food-service markets to retail grocery stores, creating logistical and packaging nightmares for plants processing milk, butter and cheese Huffstutter [13].

Therefore, dairy products in grocery stores have been in high demand as consumers stay home during the pandemic, though panic buying may be slowing Huffstutter [13]. To control the spread of the virus travel restriction was practiced. For this consequence, trucking companies that haul dairy products are scrambling to get enough drivers as some who fear the virus have stopped working. And sales to major dairy export markets have dried up as the food-service sector largely shuts down globally Huffstutter [13].

Markets and farm prices: Dairy farmers have faced a crash in milk prices amid the corona virus pandemic due to the restaurants, workplace and school shuttered across the world. In connection with the outbreak of the virus, different countries and organization were announced varieties of recommendations like social distancing, reduced travel, avoiding crowds, closures of school and restaurants and applied other protective practices to slow the spread of COVID-19, consumers was made tough choices about food, eating away from home, and overall spending. Dairy is prominently featured in out-of-home eating, and there may be some disruptions in food service sales. This has an impact on markets and prices of dairy product. There have also been bottlenecks at ports in other countries as ships wait to be offloaded with U.S. dairy and other farm products. The Chicago Mercantile Exchange has shut down floor trading of all products until "further notice," though electronic trading was practiced [14].

Concerns about the impact of the virus on the broader economy are likely to have an even larger impact on dairy prices. Many countries of the European Union were already hovering just above a recession prior to the viral outbreak and this event is likely to push them over the edge. Prior to this event, China was also experiencing slower economic growth. The U.S. has enjoyed strength in the economy, but there have been leading indicators prior to pandemic concerns that suggested that we were past the peak of the business cycle and that an economic slowdown, or perhaps that a recession was coming [14].

Jennifer Huson (2020) of the dairy farmers of America said, the demand for milk was decrease approximately 12 to 15 percent across the entire United States and those demand changes are resulting in a lot of uncertainty. Before 
the pandemic hit the United States, dairy farmers had already faced drops in prices by roughly 40 percent over the last six years, a dip that has come as a result of a glut of product in the American dairy market, the expansion of corporate farming and an increase in the customer consumption of milk alternatives, such as soy, almond and oat milk.

Maxwell a Cinnamon Ridge dairy farm owner explained that, due to COVID-19 pandemic the price of milk has really gone down. He stated as a gallon of milk is sold to $\$ 1.25$.

Like dairy farm in other countries, dairy farm found in India is hurted with outbreak of COVID-19 pandemic. Pandey the dairy farmers in Indian city Mumbia stated that, with all the restaurants and shop shut, the requirement of milk gone down drastically. Over $60 \%$ of the milk has been sold to these shops and the $40 \%$ goes to the local customers. Due to the lockdown, milk prices are now hovering at USD 0.65 cents (INR 40) per litre. Pandeny further added that there is a little hope for small dairy farmers to survive this crisis. Currently, $25 \%$ of the milk supplied to Mumbia is sourced from Aarey milk colony. On an average, a dairy farmer in Aarey owns about 50 cattle. If the lockdown continues each dairy farm owner stands to lose approximatly USD \$6,500 (INR 500,000) each month.

Supply chains slowdowns and shortages: As logistics are disrupted and efforts proceed to slow the spread of the virus, multiple connected industry sectors are already being impacted. With some products, "panic buying" is creating additional concern. As an example of supply chain interruptions on farms, the American Veterinary Medical Association (AVMA) suggests the potential for animal pharmaceutical products to be in short supply for at least some of the larger drug manufacturers. If the virus were to spread more broadly in an agricultural state like Wisconsin, issues with farm product delivery and pickup as workers - milk truck drivers for example - stay home due to illness or because they are caring for family members or school-age children. In an extreme case, utilities like electricity, natural gas, propane - based on input availability or labor shortages was observed. However, utility companies generally do a good job of contingency planning which helps buffer the impact of unforeseen events [14].

Bring the dairy farm to home business: Pennsylvania is one of the state found in United State of America and also the top 10 US states with the highest number of milk cows. It accounts for approximately $15.9 \%$ of dairy farms in the US.A home milk delivery business, in Pennsylvania, US was initially set up to deliver milk to local communities who found that it wasn't alwaysconvenient to get hold of fresh farm products. The delivery business, Cow Belle, sought to meet local demand and needs. Since 2016 Cow Belle has seen a steady upward growth, however in recent time the business has been experiencing massive demand and exponential growth [15].

As the review from [15] showed, Cow Belle was set up in 2016 by Angie Rondolet. During the outbreak of the virus the Cow Bell owner, Angie saw a gap in the market and a need for home milk delivery in Pennsylvania. Angie says, "I noticed that more and more families were looking for local, organic milk and other farm-fresh products and it wasn't always convenient to get them. So, I decided to fulfil the need and bring the farm to their homes." Currently, Angie runs the home milk delivery business with her husband to help keep up with the skyrocketing demand for deliveries.

The Cow Belle customers place their orders via the company website. Based on the customers order the company offers varities of dairy product like raw milk, whole milk, 98.5\% fatfree milk, chocolate milk, whole cream line milk, skim milk, half and half, and heavy cream.The farm also delivers a wide variety of other farm-fresh products like butter, yogurt, eggs, juice, cheese, beef, poultry and pork. The Cow Belle was delivered its dairy product to Monroe, Lehigh and Northampton counties and it delivers about 1,200 half gallons (1,200 × 1.9 litres) a week, with prices starting at US $\$ 1.99$ for a pint of milk.

Amidst the pandemic and the milk dumping, Cow Belle experience a tremendous surge in demand. At the moment, Angie finds it difficult to keep up with this explosive demand to serve locals in Pennsylvania.According to Angie statement, prior to the pandemic, Cow Belle made 120-160 deliveries a week but after the virus outbreakit rised to 325 weekly.

Farm workforce absenteeism: Reasoning the outbreak of COVID-19 virus, many workers were left from thier regular work. In many companies the majority of the workers were out of work particularly with school closeres and/or workers who need to stay home to care for sick or elderly family membres.The fear of this event and lack of information may also lead higher levels of absenteeism [14].

Import- export chain disruption: Amidst the outbreakand spread of COVID-19 pandemic, different kind of tranportation routine was restricted from any corner of the globe. Subsequently, dairy product import- export chain was disrupted. Report from Rabobank estimated that a total dairy import volume in China will fall by $19 \%$ in 2020 due to the onset of corona virus. Estimates were released in Rabobank's latest global dairy quarterly Q1 2020 report, which highlights how the current corona virus situation across the globe has resulted in the buyers and sellers 'scrambling to assess the market impact'.

The report has based its Chinese estimates on lower demand in retail and food service channels and buld up in milk powder stocks, on top of larger carryover stocks, as well as further expansion in local milk production through 2020. In China, dairy demand in liquid milk equivalent is predicted to fall by $8 \%$ in $1 \mathrm{H} 2020$ prior to Rabobank's previous forcast of a $2.4 \%$ increases. However, the bank anticipates that the forcat reduction will not beas severe as 2014-2015 stocking which resulted in a decline in liquid milk equivalent imports of more 
than $35 \%$ over 12 months. According to Rabobank, China's consumer buying patterns should normalise by the end of $2 \mathrm{H}$ 2020 with evidence of improvements in some supply chains already visible.

The global milk production from the big 7 global dairy exporters producers (the EU, US, New Zealand, Australia, Brazil, Argentina and Uruguay) meanwhile, is predicted to rise. For Q4 2019, year-on-year growth of dairy export was recorded as $0.8 \%$ marking its strongest quarterlygain since Q3 2018. Each region is expected to report a consistent pace in Q2 2020 with a growth rate of 1\%.

According to Rabobank, US milk production growth remains range bound although they refer to a 'slightly gloomier outlook for dairy demand in the future'. However, in EU, milk production is repotedly gaining momentum with mild winter conditions laying the foundation for a good spring flush. December 2019 saw Australia return to growth in the southern export pool, while Rabobank expects milk collection in New Zealand to decline by $1 \%$ due poor weather and disruped trade volumes to China. The combination of reduced Chinese imports, significant supply chain disruptions, including extreme competition for shipping containers across the globe, and rising dairy surpluses in export regions will keep downward pressure on global markets through much of 2020.

Finally, Rabobank stated that, there could be a greaterthan- expected negative impact on dairy demand and supply chains in the next time due to falling tourist numbers already inpacting food service sectors in several markets.

\section{Measures taken to save dairy industries from COVID-19 crisis}

Trade law reform: After the outbreak of corona virus, some countries were modifying their country law to save the economic crisis that faces dairy companies. Accordingly, the UK government was temporarily relaxing elements of the countries competition law to support the dairy industries during the COVID-19 outbreak. Before the outbreak of the disease, majority of the dairy industry found in UK was work separately. However, with the consequences of viral occurrence the UK government modifies the law which allows different dairy industries working together jointly. The intention of jointly working of different dairy industries was to address the market challenges, avoiding product wastage and maintaining productive capacity to meet future demand [16].

The UK government was already relaxed competition rules to allow retailers, suppliers and logistic services to work together. The amendment of the legislation was enables the collaboration between dairy farmers and producers so they can avoid their surplus milk going to waste and harming the environment. Jointly working could include sharing labor and facilities, cooperating to temporarily reduce production or identifying where there is hidden capacity in the supply chain for processing milk in to other dairy product such as cheese and butter [16].

Like the UK government, the US government stated as their country makes policy solution to prevent the dairy farm from economic disaster due to corona virus pandemic. Mulhern (2020), president and CEO of the National Milk Producers Federation, said: "Policy solution is needed for producers whose operations have been affected by the virus. In keeping with their mission of serving their members, regardless of the challenge, they will work with lawmakers and regulators to ensure a safe and adequate supply of milk and to mitigate potential economic harm to dairy farmers.

Resembling the UK and US governments, the EU agreed on jointly anti-crisis action in the dairy sector. In many areas of Europe, the amount of milk being produced on farms is too high for existing processing and market capacity. The spread of the corona virus is leading to major difficulties in procurement and logistics in the processing industry. This is further compounded by possible personnel shortages, as well as the collapse in demand for certain products. In order to do so, the European commission should immediately start to launch the voluntary volume reduction scheme with capping, as foreseen in the market responsibility programme. As the situation continuous to worsen as is currently expected, volume reduction must be promptly activated. In this way, a farmer was jointly reducing production in their farms. Such concerted action, coordinated at EU level, can then adapt production volume to circumstances and can keep the economic consequences.

Dairy industry unites to call for immediate action: Appeals for urgent government action to save the UK dairy industry during the corona virus crisis have been backed by the entire supply chain, including UK farming unions, Royal Association of British Dairy Farmers (RABDF), Dairy UK and the Provision Trade Federation [12].

Export routes expansion: Due to the COVID-19 pandemic, Brazil expands exports in eight countries market during the occurrence of the virus. This market expansion was driven by falling trade barriers because of corona virus pandemic [12].

Request government assistance: With the US as the new epicenter of the corona virus epidemic, agricultural sectors particularly dairy is among the many industries turning to its local, state and federal government for financial support. Based on the request of financial support the US Senate makes long day negotiations and approved $\$ 2$ trillion of which $\$ 9.5 \mathrm{bn}$ was approved to assist the agricultural sectors. Thus, the National Milk Producers Federation (NMPF), the largest organization of US dairy farmers and the International Dairy Food Association (IDFA) were the two US dairy associations which submitted their assistance request to their government $[10,12]$. 


\section{Conclusion}

This literature review was done to assess the impact of newly emerged strains of COVID-19 on life animals and dairy industry. As different literatures indicates among agricultural sectors livestocks and livestock products were highly infulenced by COVID-19 pandemics. The virus affects life animals through spotlighted of global wildlife trade, zoo animal were became sicked and missed human attention and wildlife was run ...wild. In addition to life animals, dairy product processing industry were highly suffered by the outbreak of the virus. The virus was affect dairy producers and dairy cooperatives morally and economically. Reasoning of the viral outbreak, many dairy product processing industries and dairy stock shops were shutdown for a time being. Not only industry and stock shops closer, huge volume of milk was dumped due to the school and restaurants which recieve milk from the producers were shutter. However, in order to save dairy industry from corona crisis, many countries were took different protective measures like trade law amendment, jointly working, assisting dairy industry and export route expansion.

Finally, corona virus is a global issues which impact life animal and its product on worldwide. Therefore, to eradicate this virus and to save agricultural crisis as general and livestock and livestock product as a particular cooperative work is necessary.

\section{References}

1. Stephen NJ. Korsman MMedFC Path. Human corona viruses University of Wisconsin-Madison. 2012.

2. Boileau MJ, Kapil S. Bovine Corona virus Associated Syndromes. Vet Clin North Am Collaborative Food Anim Pract. 2010 26:123-146. PubMed: https://www.ncbi.nlm.nih.gov/pubmed/20117547
3. Gabriele Ute Maier. Promoting healthy people and communities. UCCE research and workshops in San Benito, Monterey, and Santa cruz counties. 2020.

4. Peiris PSM. Health information and medical research on Novel Corona virus (2019-nCoV). 2012.

5. Moulds J. Three ways the corona virus is affecting animals around the World. World Economic Forum. 2020.

6. Byington L. Corona virus is the latest challenge to face dairy industry. Twitter. 2020.

7. Udine MM. The impact of COVID-19 on the dairy industry of Bangladesh. The business standard. 2020.

8. Church K. Corona virus crisis forces farmers to throw milk away. 2020

9. VT Digger. Some Vermont dairy farms dump milk amid uncertainty of corona virus crisis. 2020.

10. Mowry MJ. COVID Crisis Causes Dairy Surplus, Dumping. Granite State News. 2020.

11. Hillyard V, Barrett M, Waro M. Dairy farmers forced to dump milk as demand drops amid corona virus closers. 2020.

12. Byrne J. Corona virus: your one stops blog for feed, meat and dairy industry update. Silva feed. 2020.

13. Huffstutter PJ. U.S. dairy farmers dump milk as pandemic upends food markets. Economic Forum. 2020.

14. Stephenson M, Shutske J. Six impacts of COVID-19 on Agriculture. 2020

15. Dairy Global. COVID-19 impacts on the global dairy sector. 2020.

16. Department for Environment, Food and Rural affairs, Department for Business, Energy and industrial Strategy. 2020.

17. Dairy industry to join together to manage milk supply. GOV.UK.

18. Dillon J. A 'gut punch' for dairy farmers: COVID-19 downturn presents devastating crisis. 2020.

19. QUARTZ. Covid-19 has the US cheese and milk industries on the brink. United States. 2020. 